\title{
PEMBERDAYAAN EKONOMI KREATIF KARANG TARUNA KAMPUNG MALANG, KOTA SURABAYA
}

\author{
Mochamad Syaiful Arif ${ }^{1}$, Yanuar Fauzuddin², Hendrik Rizqiawan ${ }^{3}$, Andi Iswoyo ${ }^{4}$, Putra Hadi \\ Irawan $^{5}$ \\ ${ }^{1}$ Universitas Wijaya Putra \\ ${ }^{2}$ Universitas Wijaya Putra \\ ${ }^{3}$ Universitas Wijaya Putra \\ ${ }^{4}$ Universitas Wijaya Putra \\ ${ }^{4}$ RT 08 RW 04 Kampung Malang Utara, Surabaya \\ syaifularif@uwp.ac.id,yanuarfauzuddi@uwp.ac.id, hendrikrizqiawan@uwp.ac.id, andi@uwp.ac.id, \\ putrahadiirawan@gmail.com
}

\begin{abstract}
Abstrak
Kampung Malang Utara, RT 08 RW 04, Kelurahan Tegalsari, Kecamatan Tegalsari, Kota Surabaya merupakan salah satu daerah yang selama ini kurang aktif dalam menyelenggarakan kegiatan yang berbasis partisipasi masyarakat. Salah satu faktor utamanya adalah keterbatasan anggaran RT. Iuran bulanan warga sangat terbatas, mengingat kondisi ekonomi masyarakat yang kurang mendukung. Situasi sosial masyarakat yang rawan terjerat dalam kasus narkoba, perjudian dan pergaulan bebas selalu mengancam di wilayah ini. Tujuan kegiatan ini memberikan intervensi kepada kelompok karang taruna, supaya generasi pemuda di kampung malang dapat memiliki kegiatan rutin yang positif, kreatif dan produktif, sehingga tidak mudah terjerumus kegiatan-kegiatan negatif yang dapat merugikan masa depan. Metode yang digunakan dengan pemberdayaan ekonomi kreatif melalui kegiatan sosialisasi, pelatihan dan pendampingan keterampilan produksi serta bantuan modal peralatan produksi. Sosialisasi meliputi penyamaan persepsi dan pemberian motivasi guna meningkatkan partisipasi. Pelatihan dan pendampingan keterampilan produksi yang diberikan adalah pembuatan produk stik bawang dan keripik brownies. Hasil yang dicapai dalam kegiatan pemberdayan ini yaitu 1) Meningkatnya minat dan partisipasi warga, khususnya karang taruna dalam kegiatan positif di kampung; 2) Terselenggaranya pelatihan keterampilan produksi pembuatan stik bawang dan keripik brownies; 3) Para anggota karang taruna telah mampu membuat produk stik bawang dan keripik brownies yang layak jual secara mandiri.
\end{abstract}

Kata Kunci : Pemberdayaan, Ekonomi Kreatif, Karang Taruna, Kampung Malang, Surabaya

\section{PENDAHULUAN}

Sudah menjadi rahasia umum, bahwa wilayah Kampung Malang Kota Surabaya dikenal sebagai salah satu wilayah yang memiliki citra kurang baik, khususnya terkait dengan kegiatan perjudian, narkoba dan pergaulan bebas. Banyak faktor yang mempengaruhi kondisi ini, mulai dari jenjang pendidikan hingga kondisi ekonomi masyarakat di wilayah tersebut. Dari sisi jenjang 
pendidikan, tingkat sarjana S1 di wilayah tersebut belum menjadi hal yang familiar untuk dicapai. Rata-rata jenjang pendidikan yang mampu ditempuh oleh masyarakat di wilayah tersebut adalah SMA atau sederajat. Hal tersebut salah satunya dipengaruhi oleh kondisi ekonomi yang terbatas. Jenjang pendidikan yang terbatas membuat daya saing sebagai tenaga kerja rendah, sehingga menimbulkan tingkat pengangguran yang cukup terasa di wilayah tersebut. Kondisi ini sering kali mengarahkan kepada hal-hal yang kurang positif (Budianto dkk., 2018). Keterbatasan ekonomi membuat masyarakat mencari jalan pintas untuk mendapatkan uang dengan cara berjudi dengan bermacam-macam bentuk, mulai dari judi bola hingga judi adu merpati. Tidak sedikit pula yang terjerumus dalam lingkaran narkoba, mulai dari hanya sebagai pengguna hingga pengedar. Beberapa kali juga terdapat masyarakat kampung malang yang harus menikah di usia dini dikarenakan perilaku pergaulan bebas (hamil di luar nikah). Informasi ini berdasarkan hasil eksplorasi melalui wawancara dengan Bapak Putra Hadi Irawan, Ketua RT 08 RW 04, Jalan Kampung Malang Utara, Kelurahan Tegalsari, Kecamatan Tegalsari, Kota Surabaya.

Mencegah lebih baik daripada mengobati. Ketua RT (Bapak Putra Hadi Irawan) memiliki harapan untuk menghidupkan kampungnya dengan kegiatan-kegiatan positif, kreatif dan membangun. Namun selama ini belum terealisasi, dimana salah satu faktor utamanya adalah keterbatasan anggaran $\mathrm{RT}$. Iuran bulanan warga sangat terbatas, mengingat kondisi ekonomi masyarakat yang kurang mendukung. Sebagai langkah terobosan, Ketua RT ingin memberikan intervensi kepada kelompok karang taruna. Hal ini dikarenakan supaya generasi pemuda di kampungnya dapat memiliki kegiatan rutin yang positif, kreatif dan produktif. Sehingga generasi muda di kampungnya tidak mudah terjerumus kepada kegiatan-kegiatan negatif yang dapat merugikan masa depan mereka. Jl. Kampung Malang Utara, RT 08 RW 04, Kelurahan Tegalsari, Kecamatan Tegalsari, Kota Surabaya, memiliki geografis hanya sepanjang satu gang kecil. Di RT tersebut terdapat 63 Kepala Keluarga. Jumlah total anggota karang tarunanya adalah sembilan orang dengan karakteristik pada tabel berikut.
Tabel 1. Profil Mitra (Karang Taruna, RT 08 RW

04, Kampung Malang Utara, Kelurahan Tegalsari, Kecamatan Tegalsari, Surabaya)

\begin{tabular}{clcc}
\hline No & \multicolumn{1}{c}{ Nama } & Usia & Jabatan \\
\hline 1 & Rendra & 15 tahun & Ketua \\
2 & Selvi Putri Aulia & 18 tahun & Sekretaris \\
3 & $\begin{array}{l}\text { Rayhan Al } \\
\text { Hakim }\end{array}$ & 17 tahun & Bendahara \\
4 & Mufida & 15 tahun & Anggota \\
5 & Farah Hafizah & 17 tahun & Anggota \\
6 & Andani & 16 tahun & Anggota \\
7 & Rasyad Al Bahiq & 15 tahun & Anggota \\
& Iqbal & 15 tahun & Anggota \\
& Firmansyah & & \\
9 & Andiego & 14 tahun & Anggota \\
\hline
\end{tabular}

Sumber: Karang Taruna, RT 08 RW 04, Kampung Malang Utara, Kelurahan Tegalsari, Kecamatan Tegalsari, Surabaya

Kegiatan karang taruna selama ini sangat pasif, hanya memiliki kegiatan pada saat peringatan kemerdekaan negara Indonesia. Di luar kegiatan tersebut, para anggota karang taruna menjalani aktivitasnya masing-masing dan terkesan individualis. Mayoritas dari mereka menjalani pergaulan sehari-hari di luar kampung. Namun ketika Tim Pengabdian Masyarakat berbincangbincang dengan mereka, mereka sebenarnya memiliki potensi untuk kegiatan yang kreatif dan produktif. Mereka menginginkan hal tersebut karena sering melihat berita-berita, baik melalui jejaring sosial media maupun berita online, mengenai aktivitas produktif karang taruna di daerah-daerah lain. Secara komunitas, mereka ingin membangun kegiatan yang kreatif dan produktif, namun karrena keterbatasan modal dan pengetahuan 
untuk memulainya, maka keinginan tersebut tidak kunjung terealisasi.

Dari diskusi antara Tim Pengabdian Masyarakat dan Pihak Karang Taruna beserta Ketua RT, disepakati untuk menyelenggarakan kegiatan pemberdayaan karang taruna di RT 08 RW 04. Adapun beberapa potensi yang dimiliki karang taruna dalam menunjang kegiatan tersebut, salah satunya kemampuan dalam bermedia sosial. Salah satu anggota karang taruna, yaitu Selvi Aulia Putri memiliki akun instagram dengan follower sebanyak 866. Selain itu, anggota lainnya yang bernama Andiego, meskipun usianya masih 14 tahun, namun sehari-harinya berjualan online sebagai reselller melalui Whatsapp. Ketua Karang Tarunanya sendiri yang bernama Rendra, di usianya yang masih belia (15 tahun), di luar jadwal sekolahnya, bekerja sebagai kurir pengirim barang pesanan milik tetangga-tetangganya. Sembari mengirimkan barang pesanan, Rendra juga sering kali menawarkan produk-produk milik tetangganya (jilbab, minuman sinom, dsb) kepada pelanggannya. Dan tidak sedikit pula dari yang dia tawarkan, ada pelanggan yang tertarik.

Dari analisis situasi yang dilakukan, urgensi kegiatan Pemberdayaan Karang Taruna di Kampung Malang Utara, RT 08 RW 04, Kelurahan Tegalsari, Kecamatan Tegalsari, Kota Surabaya ini adalah dalam rangka mencegah terjerumusnya pemudi dan pemuda di wilayah tersebut ke dalam bentuk-bentuk kegiatan kenakalan remaja, sehingga mampu menjadi generasi yang aktif dalam kegiatan positif dan membangun. Kegiatan pemberdayaan yang diberikan dibidang ekonomi kreatif, yaitu membuat suatu produk makanan ringan yang bernilai ekonomi. Rasionalisasi dipilihnya kegiatan ini adalah bahwa siklus pembuatan produk makanan ringan mulai dari awal hingga menjadi produk jadi tidak menyita waktu lama (Sajar \& Refnizuida, 2019), sehingga tidak mengganggu anggota karang taruna yang masih bersekolah. Pembuatan produk makanan ringan merupakan kegiatan produksi, mulai dari menyiapkan bahan baku, mengolah bahan baku dan memasaknya menjadi produk jadi, sehingga dari proses tersebut terdapat pembelajaran mengenai kreativitas, kedisiplinan, cipta, karya dan karsa serta rasa (Suprayoga dkk., 2016). Hal-hal tersebut mampu membangun pribadi agar remaja karang taruna menjadi generasi yang kreatif dan produktif (Hadromi, 2017). Dari urgensi dan rasionalisasi kegiatan tersebut, kegiatan ini bertujuan untuk memberikan ketrampilan membuat produk makanan ringan yang bernilai ekonomi kepada Karang Taruna Kampung Malang Utara, RT 08 RW 04, Kelurahan Tegalsari, Kecamatan Tegalsari, Kota Surabaya, agar Karang Taruna di wilayah tersebut menjadi generasi penerus yang aktif dan produktif sehingga terhindar dari kenakalan remaja.

Dari uraian yang telah dikemukakan, permasalahan dan solusinya dipetakan dalam tabel berikut.

Tabel 2. Permasalahan dan Solusi

\begin{tabular}{|c|c|c|}
\hline Aspek & Permasalahan & Solusi \\
\hline $\begin{array}{l}\text { Kegiatan } \\
\text { Produktif }\end{array}$ & $\begin{array}{l}\text { Karang Taruna } \\
\text { hanya aktif pada } \\
\text { kegiatan } \\
\text { peringatan hari } \\
\text { kemerdekaan } \\
\text { Negara } \\
\text { Indonesia (17 } \\
\text { Agustus) }\end{array}$ & $\begin{array}{l}\text { Menyelenggarakan } \\
\text { Pelatihan yang } \\
\text { dilakukan secara } \\
\text { terbuka di dalam } \\
\text { wilayah kampung } \\
\text { malang utara } \\
\text { dengan peserta dari } \\
\text { Karang Taruna }\end{array}$ \\
\hline $\begin{array}{l}\text { Ketrampil } \\
\text { an } \\
\text { Membuat } \\
\text { Produk }\end{array}$ & $\begin{array}{l}\text { Belum memiliki } \\
\text { keterampilan } \\
\text { dalam membuat } \\
\text { produk apapun }\end{array}$ & $\begin{array}{l}\text { Memberikan } \\
\text { pelatihan } \\
\text { keterampilan } \\
\text { produksi makanan } \\
\text { ringan }\end{array}$ \\
\hline $\begin{array}{l}\text { Peralatan } \\
\text { Produksi }\end{array}$ & Belum Memiliki & $\begin{array}{l}\text { Bantuan peralatan } \\
\text { produksi }\end{array}$ \\
\hline \multirow[t]{2}{*}{ Potensi } & $\begin{array}{l}\text { Potensi yang } \\
\text { kurang } \\
\text { dioptimalkan }\end{array}$ & $\begin{array}{l}\text { Memberikan } \\
\text { pendampingan } \\
\text { dalam melakukan } \\
\text { produksi makanan } \\
\text { ringan hingga layak } \\
\text { jual. }\end{array}$ \\
\hline & & $\begin{array}{l}\text { Memberikan } \\
\text { pendampingan } \\
\text { untuk }\end{array}$ \\
\hline
\end{tabular}


mengoptimalkan

potensi yang

dimiliki tiap

individu dalam

menjual makanan

ringan yang

diproduksi
Pemudi dan pemuda merupakan generasi penerus bangsa dan menjadi faktor utama keberhasilan pembangunan nasional (Rudianto dkk., 2020). Pada usia remaja, mayoritas pemudi dan pemuda memiliki kondisi emosional yang masih labil. Kondisi ini membuat mereka rawan terjerumus pada situasi-situasi negative, seperti penggunaan obat-obat terlarang, perjudian, pergaulan bebas hingga tindakan kekerasan (Trisnowati dkk., 2020). Dengan intervensi yang tepat melalui program pendidikan, fasilitasi, pendampingan dan partisipasi seluruh elemen masyarakat, akan mampu membentuk generasi yang kreatif, inovatif dan produktif (Moch Wispandono, 2019).

Seringkali, pemudi dan pemuda dapat dengan mudah terjerumus dalam situasi-situasi yang negative dikarenakan kurangnya media penyaluran kreatifitas. Faktor ekonomi keluarga dan kurang tepatnya sasaran program pemerintah seringkali menjadi sebab keterbatasan tersebut (Musfiroh dkk., 2021). Program-program pemberdayaan dapat menjadi cara untuk memberikan media kepada para pemudi dan pemuda dalam menyalurkan kreatifitas, inovasi dan produktifitas yang mereka miliki (Akbar dkk., 2020). Dan tentunya di masa saat ini, telah banyak bermunculan pengusaha-pengusaha yang usianya masih sangat muda.

\section{METODE}

Metode pelaksanaan yang digunakan dalam kegiatan ini adalah 1) Sosialisasi; 2) Pelatihan; 3) Bantuan Peralatan Produksi; 4) Pendampingan. Sosialisasi dilakukan kepada Pengurus RT, Tokoh Masyarakat dan khususnya kepada Karang Taruna RT 08 RW 04, Kampung Malang Utara, Kelurahan Tegalsari, Kecamatan Tegalsari, Kota Surabaya. Sosialisasi diberikan untuk memberikan pemahaman mengenai pentingnya kegiatan yang dilakukan dan manfaat yang akan didapatkan. Dalam sosialisasi juga dibahas mengenai teknis pelaksanaan kegiatan.

Pelatihan dilakukan untuk memberikan keterampilan dalam melakukan sesuatu (Arif \& Fauzuddin, 2017). Pelatihan yang diberikan adalah pelatihan keterampilan produksi membuat makanan ringan. Dalam pelatihan ini mengundang narasumber pelaku UMKM yang sukses dalam bidang makanan ringan. Produk makanan ringan yang diajarkan adalah Stik Bawang dan Keripik Brownies. Peserta pelatihan dikhususkan untuk Karang Taruna. Pelatihan diselenggarakan secara terbuka di wilayah RT 08 RW 04, Kampung Malang Utara, Kelurahan Tegalsari, Kecamatan Tegalsari, Kota Surabaya, agar dapat juga menggugah minat dan semangat warga sekitar dalam berkegiatan di kampungnya.

Dalam membuat sesuatu, peralatan merupakan hal penting (Fauzuddin dkk., 2019). Oleh karena itu agar pelatihan produksi makanan ringan tidak hanya sekedar menjadi one-moment show saja, maka peserta perlu dibantu peralatan produksi. Sehingga setelah selesainya pelatihan, peserta dapat melakukan praktik secara mandiri.

Pendampingan dilakukan untuk memberikan pengarahan dan pengendalian mengenai komitmen dan konsistensi dalam melakukan produksi makanan ringan (Rizqiawan dkk., 2019). Pendampingan ini juga dilakukan untuk menanamkan nilai-nilai kreatifitas, produktifitas dan kedisiplinan kepada Karang Taruna.

Total jangka waktu dalam kegiatan ini adalah 3 bulan, mulai dari Juli hingga September 2021. Setelah bulan September masih terdapat beberapa kegiatan yang berorientasi pada pemasaran dan penjualan produk yang dihasilkan.

\section{HASIL DAN PEMBAHASAN}

\section{Sosialisasi}

Kegiatan sosialisasi dilakukan untuk 1) Menjelaskan maksud dan tujuan kegiatan; 2) Memberikan motivasi kepada Karang Taruna; 3) Membahas rencana materi dan teknis pelaksanaan 
kegiatan; dan 4) Membagi pengalaman sukses dari pelaku usaha mikro dan kecil. Maksud dan tujuan kegiatan disampaikan kepada Ketua RT, Tokoh Masyarakat dan seluruh anggota Karang Taruna. Sosialisasi dilakukan dengan mendatangi langsung lokasi pelaksanaan kegiatan. Dalam penyampaian tersebut, Ketua RT dan Tokoh Masyarakat menyambut dengan antusias, karena memang selama ini di wilayahnya tidak pernah menyelenggarakan kegiatan pemberdayaan untuk warganya. Baik Ketua RT maupun Tokoh Masyarakat mendukung penuh penyelenggaraan kegiatan pemberdayaan dan bersedia berbagi kontribusi. Kontribusi yang diberikan oleh warga melalui Ketua RT dan Tokoh Masyarakat adalah lokasi, perlatan dan perlengkapan penyelenggaraan pelatihan yang memadai, mulai dari tempat, sound system, serta bahan dan alat memasak.

Seluruh anggota karang taruna pun juga antusias dalam menyambut kegiatan ini. Semangat mereka ingin dapat menghasilkan suatu produk yang dapat dijual. Tidak perlu melakukan intervensi yang berat untuk menumbuhkan motivasi mereka. Banyak sekali ide yang langsung diutarakan oleh para anggota karang taruna tersebut, mulai dari produk cinderamata, minuman, hingga makanan. Dan kesepakatan yang dihasilkan adalah membuat makanan ringan. Makanan ringan ini dipilih karena mudah untuk dibuat, tidak membutuhkan waktu lama, dan hasilnya dapat disimpan dalam kurun waktu cukup lama. Jika produk yang dibuat cukup sulit, maka akan dibutuhkan pelatihan yang tidak singkat, sehingga senderung akan dapat mempengaruhi penurunan motivasi dari mereka. Jika produk membutuhkan waktu cukup lama untuk dihasilkan (misal cinderamata, baju, kerajinan), maka akan mengganggu kegiatan pendidikan formal mereka. Dan juga, jika produk yang dihasilkan tahan lama, maka produk tersebut tidak harus segera dipasarkan, sehingga ketika selesai produksi, para anggota karang taruna tidak perlu langsung berpikir untuk menjualnya hingga habis. Tentunya hal tersebut akan lebih membuat mereka lelah dan akan mengganggu kegiatan sekolahnya.
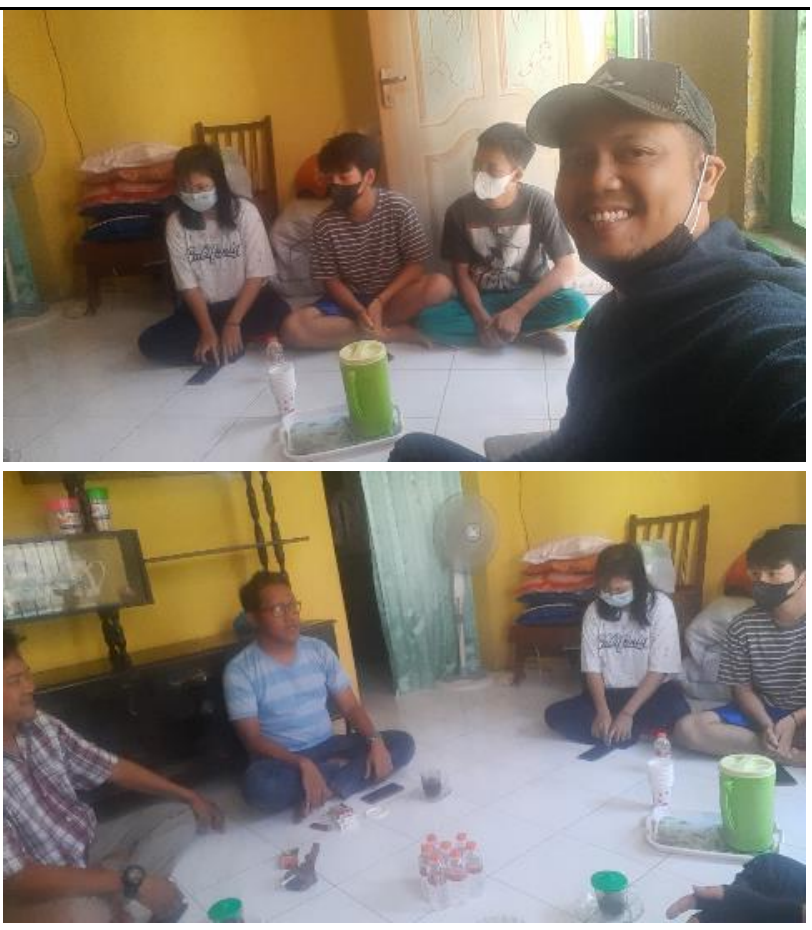

Gambar 1. Sosialisai Kegiatan Kepada Pengurus RT, Tokoh Masyarakat dan Karang taruna

Setelah menentukan jenis produk yang akan dihasilkan, anggota karang taruna diajak mengunjungi pelaku usaha mikro dan kecil yang sukses dalam memproduksi dan memasarkan serta menjual produk-produk makanan ringan. Pelaku usaha mikro dan kecil yang dikunjungi adalah binaan dari pemerintah, yang memulai usahanya mulai dari nol, dan kini telah sukses memasuki outlet-outlet jajanan oleh-oleh di jawa timur serta bandara-bandara. Pelaku usaha tersebut bernama Ibu Sudarwi Yuliningsih (Bu Ningsih), dengan produknya bernama Ricetta. Dari hasil kunjungan tersebut, para anggota karang taruna tertarik untuk membuat produk Stik Bawang dan Keripik Brownies. Ketertarikan tersebut karena Stik Bawang merupakan makanan ringan yang digemari semua kalangan, mulai dari anak-anak hingga orang tua, sedangkan keripik brownies merupakan makanan ringan yang bisa memberikan nilai jual tinggi karena berbahan dasar coklat dengan modal bahan yang tidak banyak. 
Motivasi para anggota karang taruna semakin meningkat ketika mendengar pengalaman usaha yang dijalankan Bu Ningsih. Dengan kondisi terlilit hutang, Bu Ningsih memulai usaha makanan ringannya sejak tahun 2016 dan kini telah mampu memasok outlet-oulet jajanan oleh-oleh ternama, seperti Patata dan Kios Oleh-Oleh di Bandara. Bahkan penghasilannya tiap bulan kini melebihi penghasilan suaminya. Selain itu, Bu Ningsih juga mampu memberdayakan tetangga-tetangganya untuk bersama menjalankan usaha makanan ringan, hingga Bu Ningsih ditunjuk menjadi Koordinator Pelaku Usaha Mikro dan Kecil di wilayah Kecamatan tempat tinggalnya. Mendengar cerita tersebut secara langsung, para anggota karang taruna menjadi lebih bersemangat untuk segera memulai kegiatan pelatihannya. Dan yang langsung menjadi narasumber pelatihan adalah Bu Ningsih.

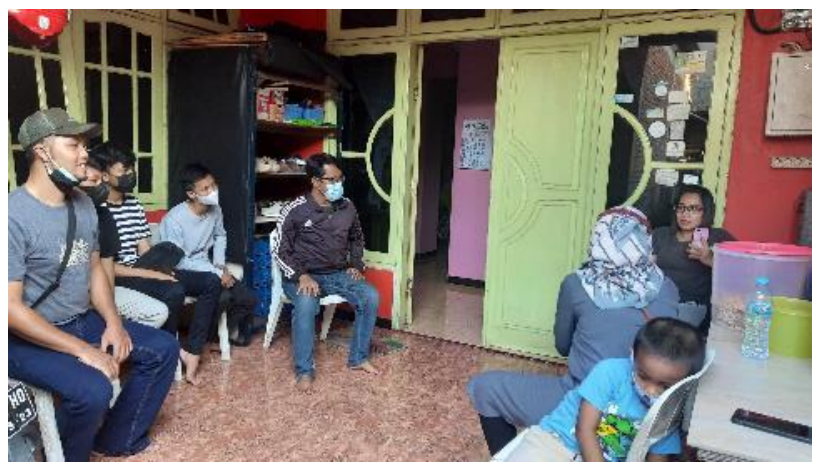

Gambar 2. Kunjungan ke Pelaku Usaha Mikro dan Kecil Makanan Ringan

\section{Pelatihan Keterampilan}

Sesuai dengan rencana yang disepakati dalam kegiatan sosialisasi, pelatihan keterampilan yang diselenggarakan adalah pelatihan membuat stik bawang dan keripik brownies. Pelatihan diselenggarakan sebanyak satu kali. Meski memiliki Balai RW yang dapat digunakan sebagai kegiatan warga, pelatihan sengaja diselenggarakan di pelataran jalan RT 08 RW 04. Hal ini bertujuan untuk menarik perhatian warga lainnya selain peserta pelatihan (anggota karang taruna). Dengan begitu, yang selama ini di wilayah tersebut tidak pernah menyelenggarakan kegiatan yang positif dan membangun, maka diharapkan ada ketertarikan dari warga yang melihat untuk semakin pro-aktif kedepannya dalam berkegiatan positif di kampungnya. Dan memang benar, kegiatan pelatihan yang diselenggarakan mampu menarik perhatian warga lainnya, khususnya ibu-ibu. Sehingga dalam pelaksanaan pelatihan tersebut tidak hanya anggota karang taruna saja yang terlibat, melainkan juga ibu-ibu rumah tangga.

Pelatihan pertama, yaitu membuat stik bawang yang kemudian dilanjutkan dengan membuat keripik brownies. Pelatihan dilakukan dengan tahapan 1) Narasumber memberikan penjelasan mengenai resep; 2) Narasumber mempraktikkan cara membuat adonannya; 3) Narasumber mempraktikkan cara memasaknya; 4) Peserta diminta untuk mempraktikkan mengenai apa yang sudah ditunjukkan oleh narasumber. Dengan tahapan ini, peserta pelatihan langsung mampu menghasilkan produk stik bawang dan keripik brownies yang langsung dinilai baik dan layak jual oleh narasumber. Selama narasumber memberikan penjelasan dan cara praktik serta selama peserta melakukan praktik, peserta melakukan tanya jawab dengan narasumber. Pertanyaan yang diajukan seputar tips dalam menghasilkan produk yang baik, mulai dari campuran adonan hingga tekniknya.

Dalam praktik, tampak peserta pelatihan dari anggota karang taruna sangat cekatan dalam mengolah adonan dan memasaknya. Selesai melakuka pelatihan, para peserta diuji mengenai pengetahuannya mengenai bahan, alat dan proses produksi dalam membuat stik bawang dan keripik brownies. Pengujian dilakukan dengan memberikan pertanyaan. Hal ini sebagai bentuk asesmen, apakah materi pelatihan yang diberikan telah mampu diterima secara maksimal oleh peserta. Sebagai apresiasi, jika peserta mampu menjawab dengan sempurna pertanyaan-pertanyaan yang diajukan, maka akan diberi bantuan alat produksi. Yang menjadi penilai, apakah jawaban yang diberikan oleh peserta sudah benar atau belum adalah narasumber pelatihan. Dan dari seluruh pertanyaan yang diajukan, peserta mampu menjawabnya dengan sempurna, hingga ke detail dari setiap bahan dan alat yang digunakan serta proses dan aturannya. 


\section{FFKM \\ CSBR}

Prosiding PKM-CSR, Vol. 4 (2021)

e-ISSN: $2655-3570$

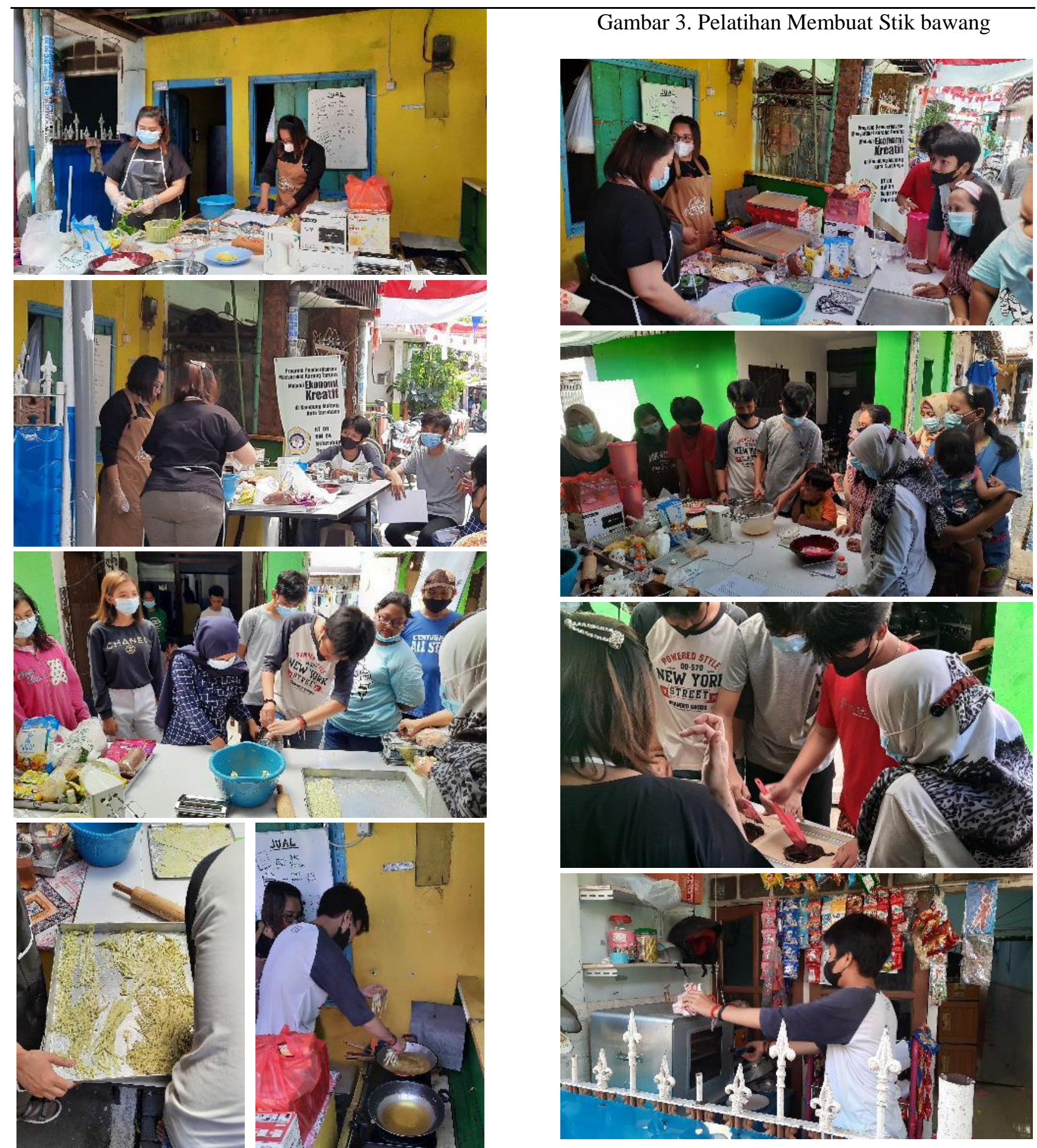

Gambar 4. Pelatihan Membuat Keripik Brownies

Ekonomi, Sosial, dan Budaya 931 


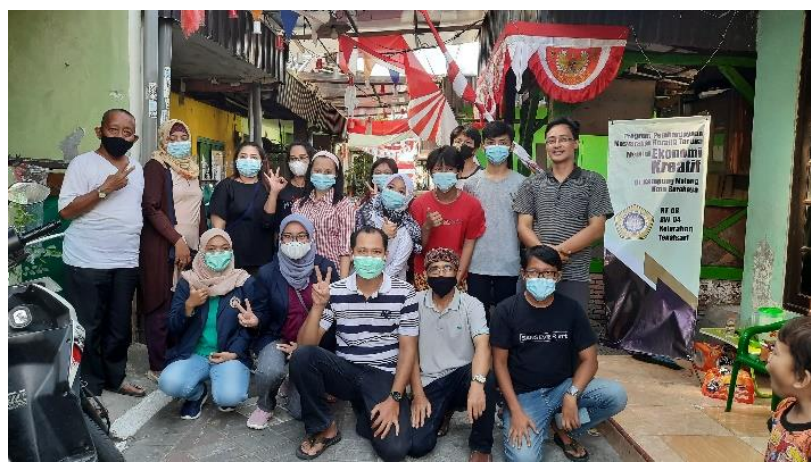

Gambar 5. Foto Bersama Seusai Pelatihan

\section{Bantuan Peralatan}

Bantuan peralatan produksi dibutuhkan agar anggota karang taruna dapat langsung mengimplementasikan keterampilan produksi yang didapat melalui pelatihan. Bantuan peralatan ini sedari awal telah diprogramkan untuk diberikan, namun agar menjadi momen yang meningkatkan motivasi, maka model pemberian bantuan peralatan ini dilakukan melalui apresiasi hasil asesmen pelatihan. Melalui model tersebut, peralatan produksi yang diterima akan menjadi sesuatu yang berharga dan akan dimanfaatkan sebaik mungkin.

Peralatan produksi yang diberikan sebagai bantuan modal yaitu oven, mixer (pengaduk adonan), penggiling adonan dan timbangan digital. Oven digunakan untuk proses memasak keripik brownies. Mixer (pengaduk adonan) digunakan untuk mencampurkan bahan-bahan stik bawang agar tercampur merata. Penggiling adonan digunakan untuk mengolah adonan stik bawang menjadi adonan yang siap masak. Timbangan digital digunakan untuk membantu menyiapkan bahan-bahan agar sesuai dengan berat yang ditentukan (presisi).

Bantuan peralatan produksi langsung diserah terimakan kepada para anggota karang taruna dan disaksikan oleh Ketua RT. Kemudian peralatan produksi tersebut diletakkan di satu tempat yang menjadi tempat berkumpul untuk melakukan praktik mandiri, sehingga perlatan yang telah diberikan tidak tersebar.
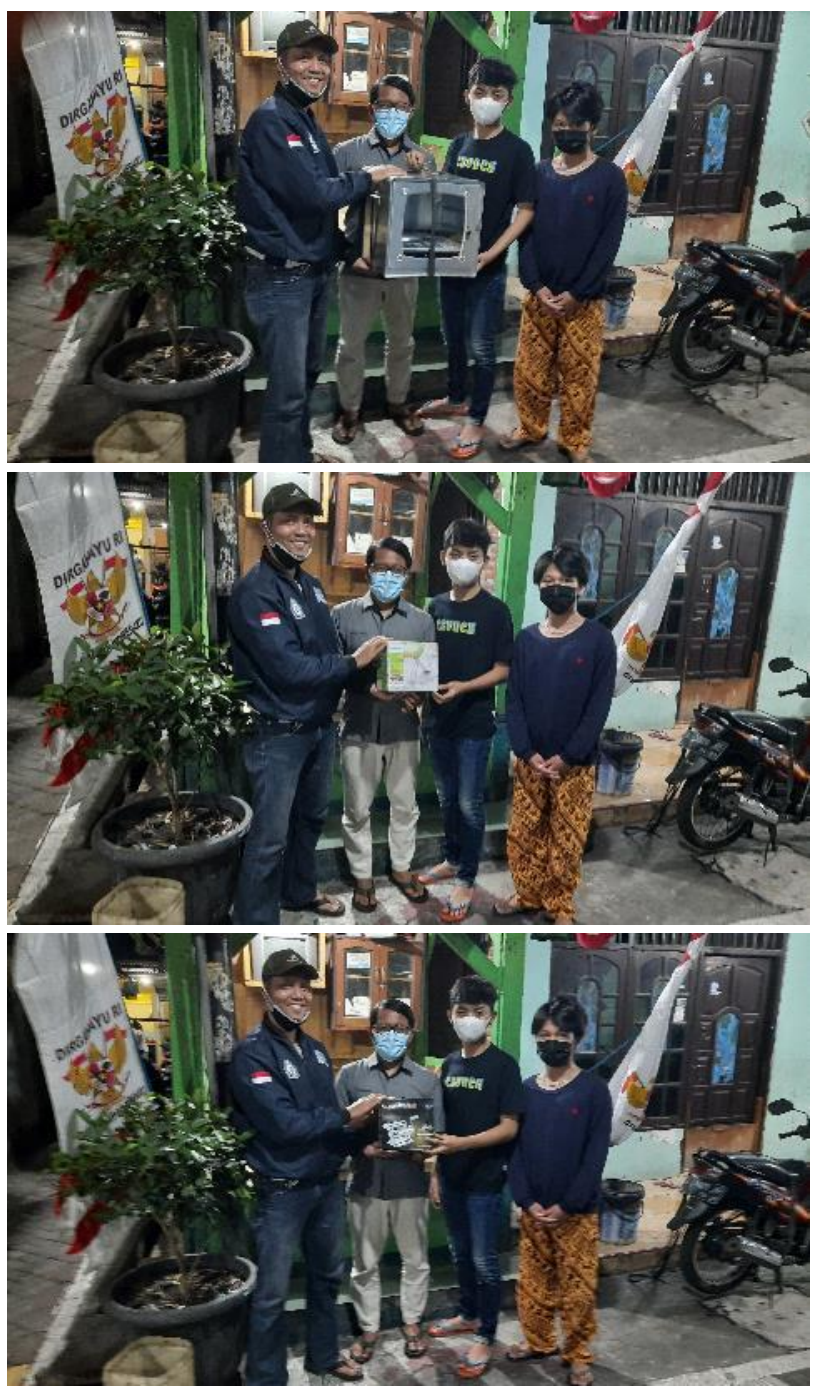

Gambar 6. Pelatihan Membuat Keripik Brownies

\section{Pendampingan}

Model pendampingan yang dilakukan yaitu, para anggota karang taruna melakukan praktik mandiri membuat stik bawang dan keripik brownies. Selama melakukan praktik mandiri tersebut, proses yang dilakukan diamati oleh tim pengabdian masyarakat. Proses yang diamati meliputi penggunaan bahan-bahan, penggunaan alat, proses pembuatan adonan dan proses memasak. Makanan identik dengan cita rasa dan tekstur, hal tersebut bergantung pada komposisi bahan yang digunakan. Jika komposisi bahan ada 
yang kurang dan berat bahan tidak tepat maka akan mempengaruhi rasa dan teksturnya.

Proses yang dilakukan secara tahap demi tahap juga diamati, apakah sudah sesuai prosedurnya atau belum. Ketidaksesuaian prosedur dapat juga mempengaruhi tekstur makanan yang dihasilkan. Misal ketika mencampur tepung dengan telur dalam membuat adonan stik bawang. Jika telur yang akan dicampurkan ke dalam tepung tidak diaduk rata terlebih dahulu maka ketika dicampurkan dengan tepung, adonan akan sulit untuk kalis, dan bahkan tidak akan menjadi kalis. Dengan melakukan hanya dua kali praktik mandiri, para anggota karang taruna telah mempu melaksanakan produksi stik bawang dan keripik brownies sesuai dengan standar yang diajarkan oleh narasumber pelatihan. Dan hasilnya, baik secara cita rasa maupun tekstur telah layak jual.
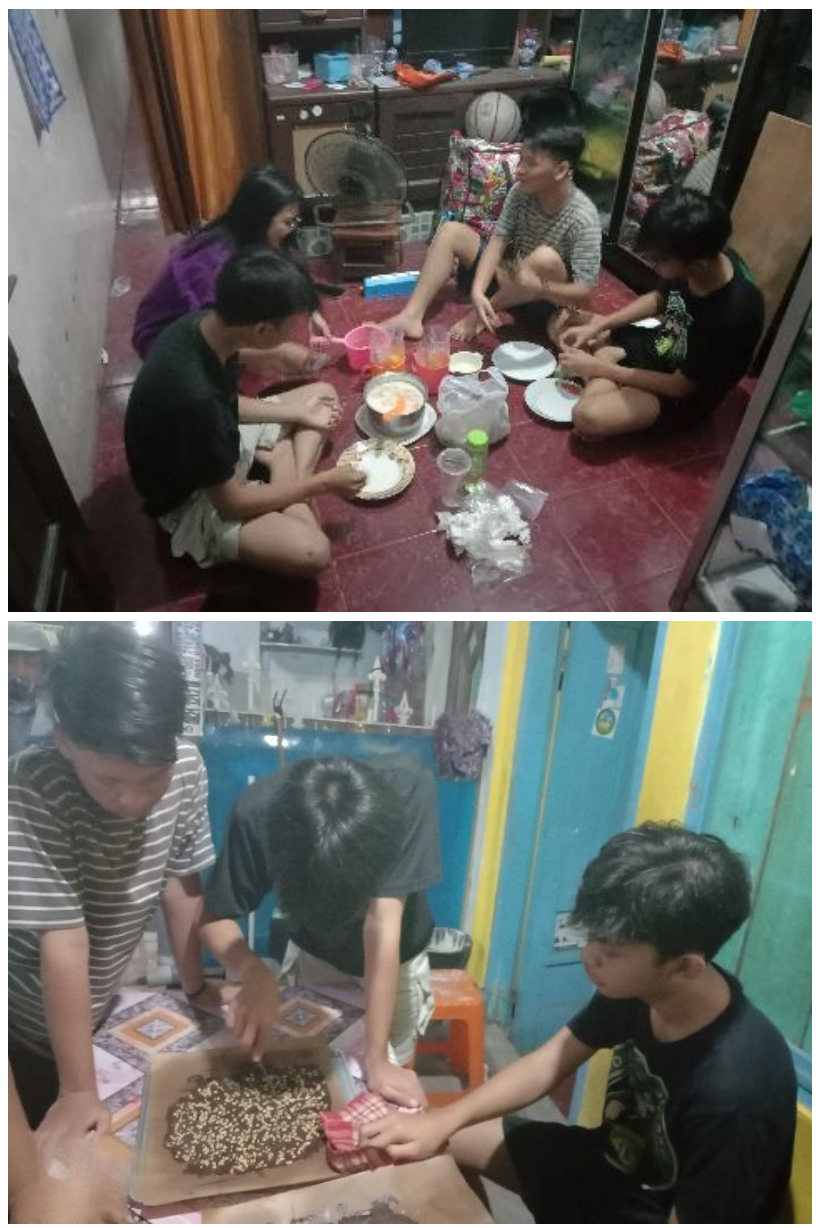

Gambar 7. Praktik Mandiri
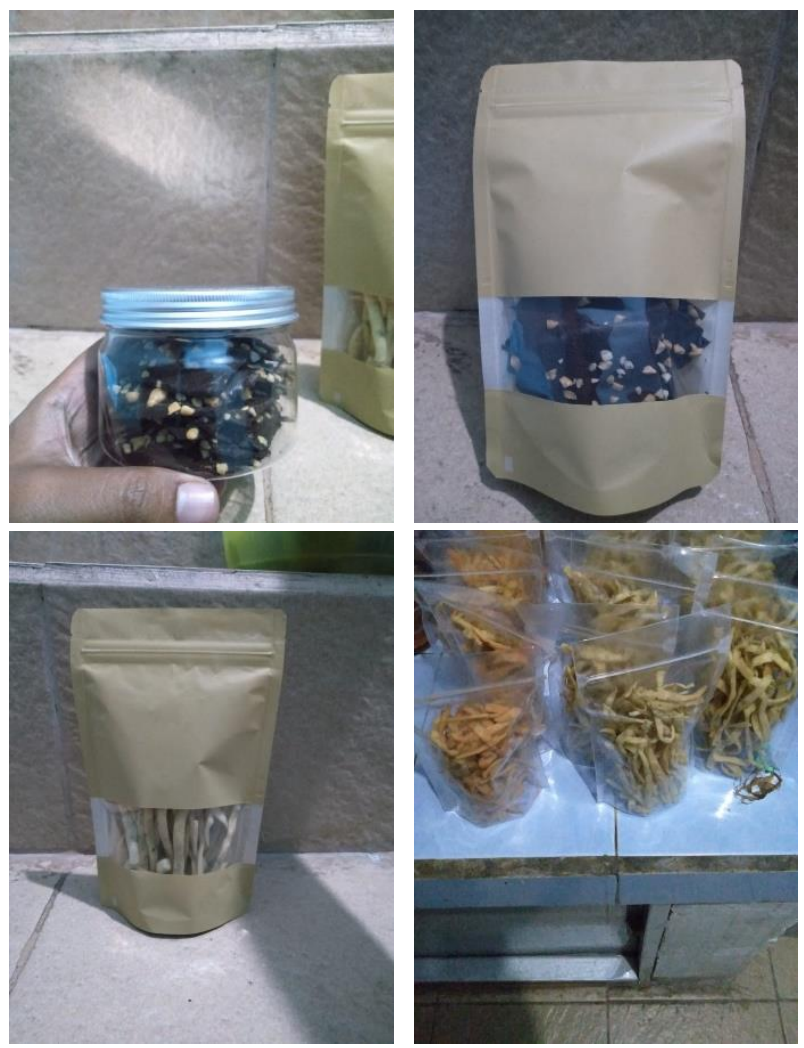

Gambar 8. Hasil Praktik Produksi (Keripik Brownies dan Stik Bawang)

Capaian kegiatan yang dihasilkan mulai dari sosialisasi hingga pendampingan sangat memuaskan. Dengan memulai dari nol, yaitu belum pernah memiliki keterampilan dalam membuat makanan, para anggota karang taruna mampu membuat produk makanan ringan stik bawang dan keripik brownies yang layak jual. Proses yang dijalani pun hanya satu kali pelatihan keterampilan dan dua kali praktik mandiri. Hasil ini sangat ditunjang dari semangat dan antusiasme yang ditunjukkan secara nyata dari seluruh pihak, mulai dari pengurus RT, Tokoh Masyarakat dan tentunya dari para anggota Karang Taruna. Dengan semangat yang tinggi dan secara teknis didukung melalui pemberian pelatihan serta pendampingan, maka kegiatan pemberdayaan akan lebih efektif dan hasilnya akan cepat dirasakan.

Tahapan selanjutnya yang akan dilakukan dalam rangkaian kegiatan pemberdayaan karang 
taruna ini adalah melakukan pemasaran dan penjualan atas produk stik bawang dan keripik brownies yang telah mampu dihasilkan. Kegiatan pemasaran yang akan dilakukan yaitu membuat kemasan dan promosi produk. Sedangkan kegiatan penjualan yang akan dilakukan adalah penetrasi pasar. Kegiatan ini direncanakan akan dilakukan pada bulan Oktober hingga Desember 2021.

\section{KESIMPULAN}

Di usia yang mayoritas masih remaja (SMP dan SMA), Karang Taruna RT 08 RW 04, Kampung Malang Utara, Kelurahan Tegalsari, Kecamatan Tegalsari, Kota Surabaya, memiliki kemampuan kreatifitas dan produktifitas yang baik. Potensi yang dimiliki setiap individu anggota Karang Taruna di RT 08 RW 04, Kampung Malang Utara, hanya membutuhkan momen kesempatan untuk memunculkannya. Pemberdayaan yang dilakukan melalui pelatihan dan pendampingan dalam menghasilkan produk bernilai ekonomi, yaitu makanan ringan stik bawang dan keripik brownies, mampu minat dan antusiasme anggota karang taruna untuk melakukan kegiatan yang produktif di wilayahnya. Dengan hanya mendapatkan satu kali pelatihan dan dua kali pendampingan, para anggota karang taruna telah mampu menghasilkan produk stik bawang dan keripik brownies yang rasa dan teksturnya layak jual. Tidak hanya itu, pelaksanaan kegiatan pemberdayaan karang taruna melalui ekonomi kreatif di Kampung Malang Utara, RT 08 RW 04, Surabaya, mampu menarik perhatian dan antusiasme warganya (tidak hanya karang taruna, melainkan ibu-ibu rumah tangga dan para bapakbapak, serta pelaku usaha mikro) untuk lebih aktif melakukan kegiatan positif di wilayah tersebut. Kegiatan pemberdayaan ini masih memiliki beberapa kegiatan lanjutan, yaitu pelatihan dan pendampingan pemasaran. Pelatihan pemasaran diperlukan untuk memberikan pengetahuan dan keterampilan mengenai kemasan dan penetrasi pasar (promosi dan penjualan).

\section{UCAPAN TERIMAKASIH}

Terima kasih kepada Lembaga Penelitian dan Pengabdian Masyarakat (LPPM) Universitas Wijaya Putra sebagai lembaga pemberi hibah pendanaan dalam kegiatan pengabdian masyarakat ini. Selain itu terima kasih kepada RT 08 RW 04, Kampung Malang Utara, Kelurahan Tegalsari, Kecamatan Tegalsari, Kota Surabaya, baik Pengurus RT, Tokoh Masyarakat dan khususnya Karang Taruna yang telah berkontribusi sebagai lokus penyelenggaraan kegiatan.

\section{REFERENSI}

Akbar, Zubair, H., \& Jamil, M. H. (2020). Strategy for developing the role of youth in agriculture of Soppeng district, South Sulawesi province. IOP Conference Series: Earth and Environmental Science, 473(1), 012050. https://doi.org/10.1088/17551315/473/1/012050

Arif, M. S., \& Fauzuddin, Y. (2017). IPTEKS BAGI MASYARAKAT (IBM) KELOMPOK IBU-IBU RUMAH TANGGA DESA BANJAREJO KECAMATAN NGADILUWIH KABUPATEN KEDIRI. AJIE, 2(1), 25-35. https://doi.org/10.20885/ajie.vol2.iss1.art3

Budianto, A. A. T., Abidin, Z., \& Paeno, P. (2018). Pemberdayaan Karang Taruna Untuk Meningkatkan Perekonomian Masyarakat. Jurnal Pengabdian Dharma Laksana, 1(1), 21-30.

Fauzuddin, Y., Murti, A. B., Karlin, K., \& Iswoyo, A. (2019). Pemberdayaan Ekonomi Ibu-Ibu Rumah Tangga Kecamatan Pakal, Kota Surabaya. Prosiding Konferensi Nasional Pengabdian Kepada Masyarakat dan Corporate Social Responsibility (PKM-CSR), 2 , 1230-1239. https://doi.org/10.37695/pkmcsr.v2i0.489

Hadromi. (2017). The pattern of performance management of community service learning empowerment in improving the entrepreneurship on the graduation candidate of Vocational Technology Education Institution. In Subiyanto, K. R., K. A., Megawati, \& W. D. (Ed.), AIP Conference Proceedings (Vol. 1818, hal. 020014). American Institute of Physics Inc. https://doi.org/10.1063/1.4976878

Ekonomi, Sosial, dan Budaya 934 
Moch Wispandono, R. M. (2019). Empowerment of Karang Taruna as an Effort to Sustainability of Rural Economic Growth in Madura Island. IOP Conference Series: Earth and Environmental Science, 255(1), 012048. https://doi.org/10.1088/17551315/255/1/012048

Musfiroh, M., Setyowati, R., Rante Ada, Y., Sholahuddin, S., \& Najib, N. (2021). Family knowledge of population issues. Journal of Public Health Research, 10(2). https://doi.org/10.4081/jphr.2021.2226

Rizqiawan, H., Karlin, K., Iswoyo, A., Murti, A. B., \& Fauzuddin, Y. (2019). Fasilitasi Inkubasi Usaha Mandiri Kecamatan Lakarsantri Kota Surabaya Tahun 2018. Prosiding Konferensi Nasional Pengabdian Kepada Masyarakat dan Corporate Social Responsibility (PKMCSR), 2, 1138-1146. https://doi.org/10.37695/pkmcsr.v2i0.702

Rudianto, Yudaningtyas, E., \& Kasitowati, R. D. (2020). Institutional capacity building of Bina Hang Tuah youth organization and Tambaan Indah waste bank in the context of plastic waste management in Tambaan Urban
Village, Pasuruan City, East Java Province, Indonesia. IOP Conference Series: Earth and Environmental Science, 584(1), 012035. https://doi.org/10.1088/17551315/584/1/012035

Sajar, S., \& Refnizuida. (2019). Pemberdayaan Karang Taruna dan Ibu PKK Sebagai Upaya Peningkatan Pendapatan Melalui Pelatihan Budidaya Jamur Tiram di Desa Timbang Lawan Kecamatan Bahorok Kabupaten Langkat. Journal of Animal Science and Agronomy Panca Budi, 4(2), 49-57.

Suprayoga, S., Iswoyo, A., \& Syahrial, R. (2016). Model Pemberdayaan Karang Taruna di Kecamatan Cerme Kabupaten Gresik. Ajie, 1(2), 134-147. https://doi.org/10.20885/ajie.vol1.iss2.art5

Trisnowati, H., Ismail, D., Padmawati, R. S., \& Utarini, A. (2020). Developing a framework for youth empowerment to prevent smoking behavior in a rural setting: study protocol for a participatory action research. Health Education, 121(1), 30-47. https://doi.org/10.1108/HE-06-2020-0045 